\title{
The first finding of myxosporean development from plasmodia to spores in terrestrial mammals: Soricimyxum fegati gen. et sp. $n$. (Myxozoa) from Sorex araneus (Soricomorpha)
}

\author{
Carol-Constantin Prunescu ${ }^{1}$, Paula Prunescu ${ }^{1}$, Zdzislaw Pucek $^{2}$ and Jiří Lom ${ }^{3}$ \\ ${ }^{1}$ Institute of Biology, Romanian Academy, P.O. Box 56-53, 296 Spl. Independentei, 060031 Bucharest, Romania; \\ ${ }^{2}$ Mammal Research Institute, Polish Academy of Sciences, Waszkiewicza 1c, 17-230 Bialowieza, Poland; \\ ${ }^{3}$ Institute of Parasitology, Biology Centre, Academy of Sciences of the Czech Republic, Branišovská 31, 37005 České \\ Budějovice, Czech Republic
}

Key words: Myxozoa, Myxosporea, Soricimyxum fegati, liver infection, development, Sorex araneus, taxonomy

\begin{abstract}
Soricimyxum fegati gen. et sp. n. is a new myxosporean (Myxozoa) species discovered in the liver of shrews, Sorex araneus L., collected in the Bialowieza primeval forest (Poland). Both developmental stages and mature spores were found during a histological study. The infection had about $40 \%$ prevalence at the investigated locality. Plasmodia were polysporic. Elongated plasmodia with an average size of 30 by $8 \mu \mathrm{m}$ occupied bile ducts and larger rounded plasmodia up to $80 \mu \mathrm{m}$ in diameter were found in liver parenchyma where they most probably entered after the ducts had been destructed. Plasmodia in both locations elicited a vigorous inflammatory reaction. Spores were of an ovoid shape, $7 \mu \mathrm{m}$ long, $5.4 \mu \mathrm{m}$ wide and about $3.5 \mu \mathrm{m}$ thick. They had two shell valves and two equal polar capsules, located in opposite ends of the spore.
\end{abstract}

The parasite described in this paper was discovered in the course of a thorough investigation into the cause of a debilitating condition of young shrews (Sorex araneus L.). The shrews have a life span of about 16-18 months; being born in May, they become adult but not yet sexually mature in the autumn. It is only in the second year that they reach sexual maturity. In the autumn and early winter of the first year many suffer from regression of body weight and dimensions, skull bone modification (Dehnel phenomenon) and there is a high mortality (Dehnel 1949, Pucek 1955, 1957, 1965, 1970). The mortality might be due to various pathogenic and ecological factors (Karbowiak et al. 2005). However, we pursued the hypothesis that the skull bone changes might perhaps be due to a parasitic disease similar to whirling disease of salmonids. Histological sections of brain and cranial bones failed to detect any agent possibly responsible for the observed pathology, whereas the examination of liver histology led to the finding and description of a myxosporean parasite showing development from plasmodia to spores.

Myxosporea (phylum Myxozoa Grassé, 1970) have been known since 1825 (see Lom and Dyková 2006) as frequent parasites of fish and also of some amphibians (Lutz 1889) and reptiles (Laveran 1897). It was as late as the turn of the last century that they were also reported from homoiothermic vertebrates including man. In stool samples of humans examined for gastrointestinal disorders, spores of the genera Myxobolus Bütschli, 1822 and Henneguya Thélohan, 1892 were found and it was presumed that they were parasites of consumed fish
(McClelland et al. 1997, Boreham et al. 1998). In another case (Moncada et al. 2001), it was speculated that the Myxobolus spores found in the stool might have been the result of an opportunistic infection of an HIVinfected patient.

The finding of a first presumed myxosporeosis of homoiothermic vertebrates was published by Friedrich et al. (2000), who found myxozoan-like presporogonic stages in the brain of mole (Talpa europaea); spores were not found. Later, Lowenstine et al. (2002) published a short communication on myxozoan infection in ducks from an American zoological garden. They found both developmental stages and mature myxospores in inflammatory lesions in the bile ducts and in hepatic parenchyma. Our finding is the first positive proof that Myxosporea are not restricted to cold-blooded and/or aquatic vertebrates and confirms that these parasites may also develop in terrestrial mammals.

\section{MATERIALS AND METHODS}

Shrews were collected between 2001 and 2005, in the Bialowieza primeval forest (Bialowieza National Park), Poland. Serial histological sections $5 \mu \mathrm{m}$ thick of the liver, kidney, spleen, diaphragm, and heart of all specimens collected were studied. Brain, tongue and skull bones or only the brain were studied in 14 animals. Haematoxylin-eosin (H\&E) stain was applied for the observation of sectioned liver revealing parasites. Haematoxylin combined with picro-Sirius red (PSR) was used to visualise collagen fibres. Ziehl-Neelsen method was used for polar capsule and filament staining. The dimensions of myxozoan spores $(\mathrm{L}, \mathrm{W}$, polar capsule diameter) $(\mathrm{n}=21)$ 
were measured with an ocular micrometer. Measurements and descriptions were based exclusively on histological sections.

\section{RESULTS}

Nineteen out of 46 shrews examined were infected with a new myxosporean species. Its description is based on sectioned material of the infected host livers.

\section{Soricimyxum gen. n.}

Polysporic plasmodia found in liver bile ducts and parenchyma of a terrestrial mammal. No pansporoblast formation observed. Mature myxospore features (Fig. 1): spore ovoid with finely striated valve surface; two equal polar capsules in opposite ends of spore; polar filaments wound in one plane, not reaching two full turns. Type and only species: Soricimyxum fegati sp. n.

\section{Soricimyxum fegati sp. $\mathrm{n}$.}

Spores (Figs. 1, 5, 6) ovoid; length $7.0 \mu \mathrm{m}$ (range 6.3-7.5), width $5.4 \mu \mathrm{m}$ (range 4.3-6.0), and thickness about $3.5 \mu \mathrm{m}(\mathrm{n}=5)$. Two spherical, equal-sized polar capsules $1.7 \mu \mathrm{m}$ (range 1.3-2.1) in diameter, positioned at opposite poles of spore with divergent orientation. Polar filament coiled at single level (Fig. 6), forming about one and half to one and two thirds of a turn. Two shell valves, joined along straight longitudinal suture, with barely visible fine longitudinal ridges. Centrally located sporoplasm with two nuclei (Fig. 5). Spores appeared singly, revealing no pansporoblast formation.

Plasmodia multinucleate, with sporogonic cells in different stages of maturation and with mature spores. Plasmodia with a thick ectoplasmic layer were localised in hepatic parenchyma (Figs. 2, 3) or in intra-hepatic bile duct lumens.

Three types of vegetative stages occurred:

1) Flat and sometimes ramified polysporic plasmodia within the bile ducts (Fig. 4). In transverse sections of bile ducts these had an average dimension of $30 \times 7-8$ $\mu \mathrm{m}$.

2) Large, polysporic, histozoic plasmodia (Figs. 2, 3, 5) viewed in cross-section had a rounded shape and a diameter of $50-80 \mu \mathrm{m}$. They were surrounded by an inflammatory infiltrate constituted by a mass of lymphocytes, including monocytes. Observation of gradual stages of damaged wall of the infected bile duct (Fig. 8) suggests that destruction of the bile duct released the plasmodia into the parenchyma (Fig. 9). Thus once coelozoic, the plasmodia became histozoic.

3) Tiny, spore-bearing plasmodia inside the epithelial layer of the bile duct wall (Fig. 7).

The numerous mature myxospores often found outside the plasmodium among the infiltrating cells (Fig. 9) came from destroyed plasmodia, a case frequently encountered in fish myxosporean infections.
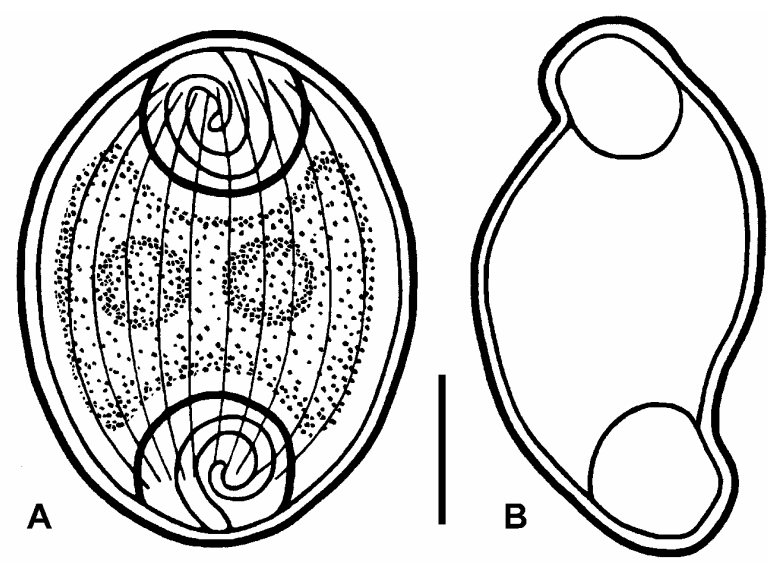

Fig. 1. Spore of Soricimyxum fegati sp. n. A - frontal view; B - lateral view. Scale bar $=2 \mu \mathrm{m}$.

T y p e h o s t: Sorex araneus Linnaeus, 1758 (Mammalia, Soricomorpha, Soricidae).

L o c a 1 i t y : Primeval forest near Bialowieza, Bialowieza National Park, $52^{\circ} 43^{\prime} \mathrm{N}, 23^{\circ} 54^{\prime} \mathrm{E}$, Poland.

$\mathrm{S}$ i t e of infectio $\mathrm{n}$ : Liver parenchyma and intrahepatic bile ducts.

P r e v a 1 e n c e : $41.3 \%$ (19 animals infected of 46 examined).

T y p e mat e r i a 1: Liver histological slides deposited in the Institute of Parasitology, Academy of Sciences of the Czech Republic, České Budějovice, Nos. DPF 012-013.

$\mathrm{E} \mathrm{t}$ y $\mathrm{m} \mathrm{o} 1 \mathrm{og}$ y: The generic name Soricimyxum is formed from the combination of the first part of the host family name Soricidae with the particle "myxum" indicating the affiliation with the phylum Myxozoa. The species name fegati is derived from "fégato" (Italian) = liver.

The infected animals and those parasite-free were analysed in relation to their age and year season at the time of capture (Table 1). The small number of winter captures might be explained by severe winters in eastern Poland. Our data confirm the supposition that the shrews became infected at the beginning of summer. During autumn more infected animals were found.

Histological examination of the brain and cranial bones of 14 individuals of Sorex araneus failed to detect any myxosporean parasites and thus the relationship between skull deformities of this animal and whirling disease of trout remains disproved.

Table 1. Prevalence of Soricimyxum fegati sp. n. in the liver of Sorex araneus (infected/examined) according to season and host age.

\begin{tabular}{llllll}
\hline \multirow{2}{*}{ Host age } & \multicolumn{4}{c}{ Season } & \multirow{2}{*}{ Total } \\
\cline { 2 - 5 } & Spring & Summer & Autumn & Winter & \\
\hline Young adults & $0 / 5$ & $3 / 9$ & $10 / 24$ & $1 / 2$ & $14 / 40$ \\
Old adults & $1 / 2$ & $3 / 3$ & $0 / 0$ & $1 / 1$ & $5 / 6$ \\
Total & $1 / 7$ & $6 / 12$ & $10 / 24$ & $2 / 3$ & $19 / 46$ \\
\hline
\end{tabular}



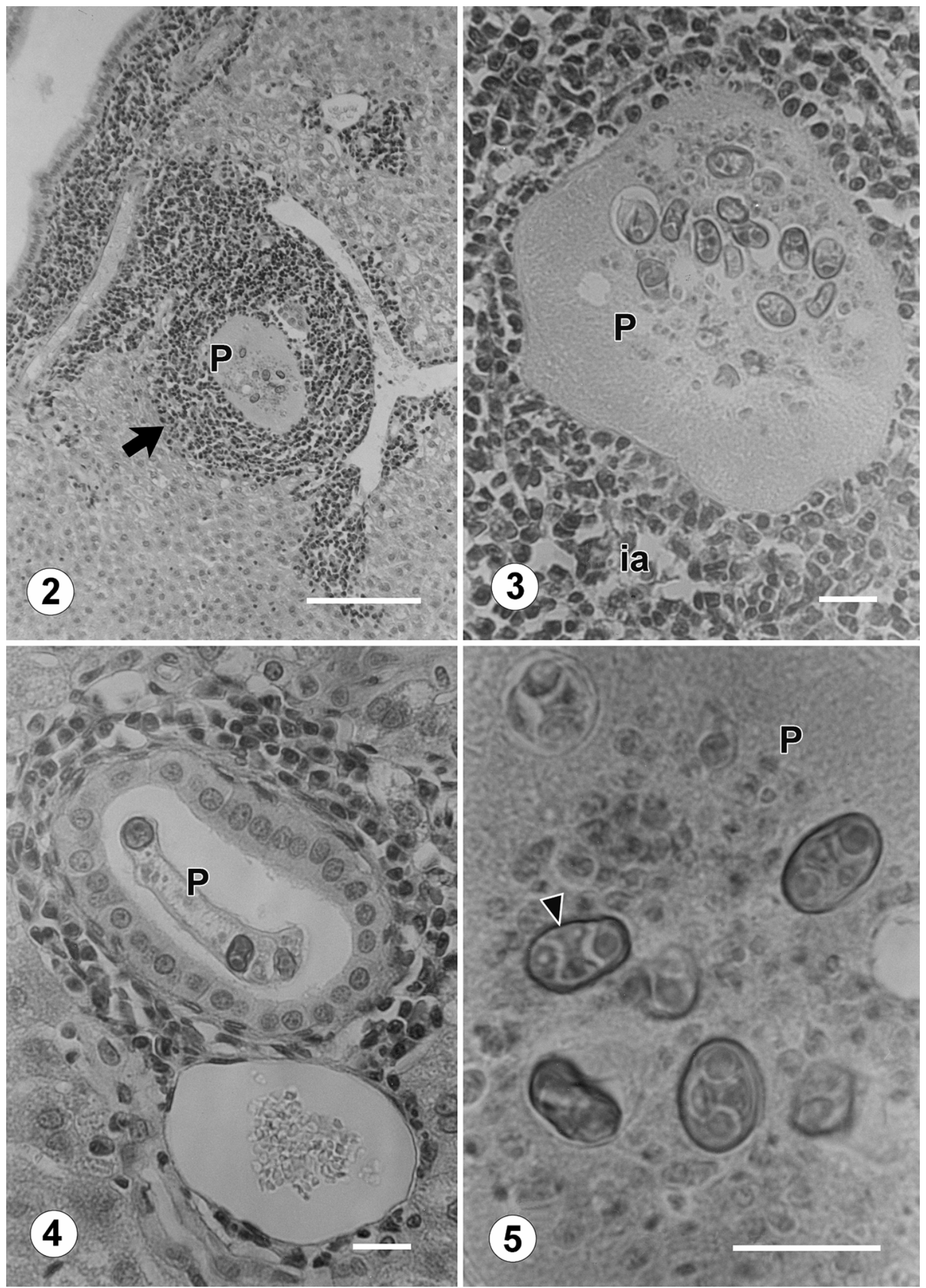

Figs. 2-5. Plasmodia of Soricimyxum fegati sp. n. in the liver of Sorex araneus. Fig. 2. Sporogonic plasmodium (P) in liver parenchyma surrounded by a large inflammation (arrow). Picro-Sirius red (PSR). Fig. 3. Plasmodium (P) with mature spores encircled by a mass of lymphocytes. ia - inflammation area. H\&E. Fig. 4. Elongated coelozoic plasmodium (P) inside the bile duct lumen. Note the presence of two mature myxospores. PSR. Fig. 5. Details of plasmodium (P) with several isolated spores. Arrowhead points at the centrally located sporoplasm between two polar capsules in the opposite ends of the spore. H\&E. Scale bars: Fig. $2=50 \mu \mathrm{m}$; Figs. $3-5=10 \mu \mathrm{m}$. 


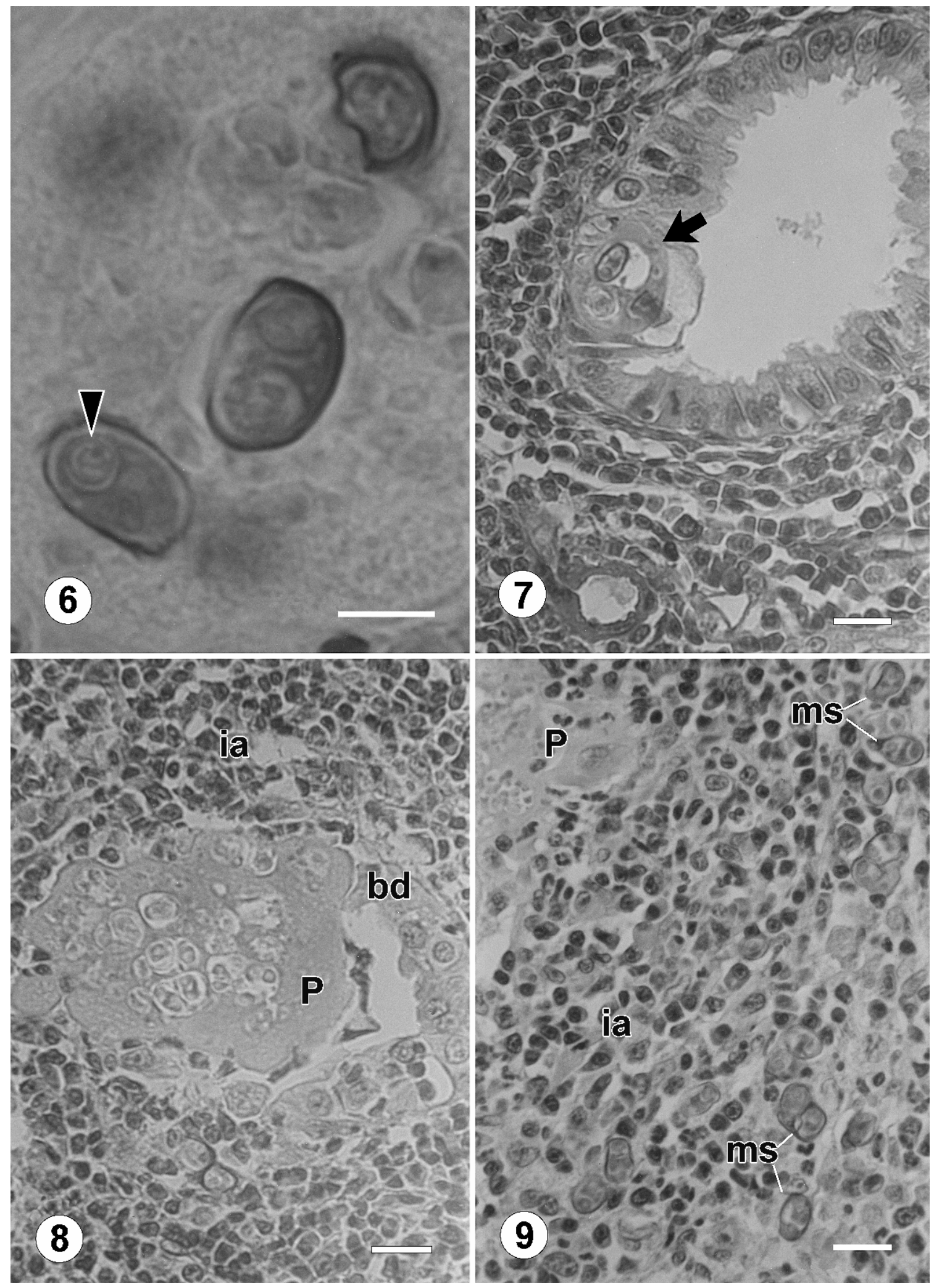

Figs. 6-9. Plasmodia of Soricimyxum fegati sp. n. in the liver of Sorex araneus. Fig. 6. Spores in the plasmodium. Arrowhead points at the polar filament wound within the polar capsule in one plane. Ziehl-Neelsen. Fig. 7. Small plasmodium (arrow) in the epithelial cell of the biliary duct wall. PSR. Fig. 8. Sporogonic plasmodium (P) and biliary duct (bd) wall remnants surrounded by inflammatory cells. ia - inflammation area. H\&E. Fig. 9. Myxospores (ms) spread among the monocytes and lymphocytes in the inflammation area (ia) around the sporogonic plasmodium (P). PSR. Scale bars: Fig. $6=4 \mu \mathrm{m}$; Figs. 7-9=10 $\mu \mathrm{m}$. 
It should be noted that many of the studied shrews presented large schizonts in the endothelial cells of the arteries in the liver and other organs. These schizonts represented asexual stages of a novel sarcosporidian species which will be described elsewhere. Furthermore, the presence of microsporidia in hepatocytes and/or in the monocytes from the inflammatory area around the myxosporidian plasmodium was infrequently noted.

\section{DISCUSSION}

The description of the first representative of the phylum Myxozoa having as the intermediate host an exclusively terrestrial mammal species, mooted the question about the fact that its definitive host must be a terrestrial organism.

In analogy with fish-infecting myxosporeans we can postulate the existence of a life cycle in which shrews represent the intermediate hosts while the definitive host may be some soil-dwelling oligochaete. Terrestrial annelids like lumbricids and enchytraeids are present in the environment of shrews, namely in the litter and humus of forests in the temperate region. They are important food resources for Sorex araneus (Churchfield and Rychlik 2006).

The actinosporean stages may enter their fish hosts by attaching themselves to the surface of the skin and invading it, as El-Matbouli et al. (1995) demonstrated for Myxobolus cerebralis. The invasive stage from the yet unknown definitive host could enter in the shrews orally. Future studies may throw light on details of myxosporean adaptation to terrestrial life and on their phylogeny.

It is feasible to postulate that invertebrates were the first hosts of ancestral myxozoans (Canning and Okamura 2004). In the course of their evolution, myxozoans achieved their two-host life cycle and then their stages adapted to various vertebrates as intermediate hosts, especially fish, amphibians, aquatic reptiles and aquatic birds. All these vertebrates are intermediate hosts for the myxozoans which could have their definitive hosts in aquatic annelids (Kent et al. 2001, Køie et al. 2004, Køie 2005). As for the terrestrial mammals like Sorex, terrestrial annelids may serve as definitive hosts for the actinosporean stage.

The myxozoan-like parasite found in the brain of Talpa europaea (Friedrich et al. 2000) might represent a similar case of adaptation to terrestrial life. However, the absence of the characteristic spores of myxozoan during all the 12 months of the year could suggest another taxonomic position or other organs for the production of the myxozoan spores.
The position of the plasmodia in the bile ducts warrants further study. Do the coelozoic forms initially adhere to the bile duct wall to detach later and float free in the lumen? In many fish coelozoic myxosporean species, both attached and free-floating forms are common (Lom and Dyková 1992).

Our observation indicates that the coelozoic plasmodia enter the parenchyma after having destroyed the bile duct wall. This is suggested by observation (e.g., Fig. 8) of large plasmodia in the space of a disorganized bile duct. It can also be presumed that a plasmodium expanding from inside of an epithelial cell of the duct wall or growing within the lumen of the bile duct may eventually cause obturation and destruction of the duct so that the plasmodia find themselves in the parenchyma. One could also speculate that the parenchyma was reached by the presporogonic stage migrating from the portal of infection through the liver, a migration demonstrated for Chloromyxum reticulatum (Dyková and Lom 1988).

As for taxonomic affinities, the general appearance of the plasmodia and spores is reminiscent of that of some species of the genera Zschokkella Auerbach, 1910 and/or Myxidium Bütschli, 1882, both having primarily coelozoic species (Lom and Dyková 1992, 2006). The appearance of the shrew parasites is surprisingly comparable to these common fish parasites. One difference from any of the two above mentioned genera is the extremely short polar filament of Soricimyxum fegati.

The main difference from any of the known myxosporean genera is represented by the intermediate host, a terrestrial mammal. This supposes a completely different biology and probably another way of transmission.

The presence of plasmodia in the bile ducts seems to be tolerated by the biliary epithelium. However, we also observed ducts that harboured degraded plasmodia having necrotic epithelia. The ducts harbouring plasmodia but still having normal epithelium elicited a host cellular response manifested by a massive lymphocytic infiltration. The lymphocyte agglomerations were most striking around the plasmodia in the parenchyma and indicate that a heavy infection could have a deleterious effect on the liver tissue. Evaluation of the rate of pathogenicity would require further studies.

Soricimyxum fegati will be assigned to a clear systematic position only after further research including: 1. molecular comparative studies to define the phylogenetic relationships of this new myxozoan; 2. experimental studies on its development in the definitive and intermediate host; 3 . research on its ultrastructure; 4 . light microscopical study of fresh spores to avoid shrinkage artefacts and damage to the shell surface ornamentation due to histological fixation. 


\section{REFERENCES}

BOREHAM R.E., HENDRICK S., O’DONOGHUE P.J., STENZEL D.J. 1998: Incidental finding of Myxobolus spores (Protozoa, Myxozoa) in stool samples from patients with gastrointestinal symptoms. J. Clin. Microbiol. 36: 3728-3730.

CANNING E.U., OKAMURA B. 2004: Biodiversity and evolution of the Myxozoa. Adv. Parasitol. 56: 43-131.

CHURCHFIELD S., RYCHLIK L. 2006: Diets and coexistence in Neomys and Sorex shrews in Bialowieza forest, eastern Poland. J. Zool. 269: 381-390.

DeHNel A. 1949: Studies on the genus Sorex L. Ann. Univ. M. Curie-Sklodowska, Lublin, Poland, Sect. C 4, 2: 17-102. (In Polish with an English abstract.)

DYKovÁ I., LOM J. 1988: Chloromyxum reticulatum (Myxozoa, Myxosporea) in the liver of burbot (Lota lota L.) and its migration to the final site of infection. Eur. J. Protistol. 23: 258261.

El-Matbouli M., HoffmanN R.W., MandoK C. 1995: Light and electron microscopic observations on the route of the triactinomyxon-sporoplasm of Myxobolus cerebralis from epidermis into rainbow trout cartilage. J. Fish Biol. 46: 919-935.

Friedrich C., IngOlic E., Freitag B., Kastberger G., HoHMANN V., SKOFITSCH G., NEUMEISTER U., KEPKA O. 2000: A myxozoan-like parasite causing xenomas in the brain of the mole, Talpa europaea L., 1758 (Vertebrata, Mammalia). Parasitology 121: 483-492.

KARBOWIAK G., RYCHLIK L., NOWAROWSKI W., WITA I. 2005: Natural infections of small mammals with blood parasites on the borderland of boreal and temperate zones. Acta Theriol. 50: $31-42$.

Kent M.L., Andree K.B., Bartholomew J.B., El-Matboul M., DeSSER S.S., DEVlin R.H., FeIST S.W., HEDRICK R.P., HofFMANN R.W., KhatTRa J., HALlett S.L., LeSter J.G., Longshaw M., Palenzuela O., Siddall M.E., XiaO C. 2001: Recent advances in our knowledge of the Myxozoa. J. Eukaryot. Microbiol. 48: 395-413.

KøIE M. 2005: The Spionidae (Polychaeta) act as invertebrate hosts for marine Myxozoa. Bull. Eur. Assoc. Fish Pathol. 25: 179-181.

KøIE M., WhipPs C.M., KeNT M.L. 2004: Ellipsomyxa gobii (Myxozoa: Ceratomyxidae) in the common goby Pomato- schistus microps (Teleostei: Gobiidae) uses Nereis spp. (Annelida: Polychaeta) as invertebrate hosts. Folia Parasitol. 51: $14-18$.

LAVERAN A. 1897: Sur une myxosporidie des reins de la tortue. C. R. Soc. Biol. Paris 49: 725-726.

LOM J., DYKOVÁ I. 1992: Protozoan Parasites of Fishes. Elsevier, Amsterdam, $315 \mathrm{pp}$

LOM J., DYKOVÁ I. 2006: Myxozoan genera: definition and notes on taxonomy, life-cycle terminology and pathogenic species. Folia Parasitol. 53: 1-36.

LOWEnStine L.J., RideOUT B.A., GARner M.M., BusCh M., MACE M., BARTHOlOMEW J., GARDiner C.H. 2002: Myxozoonosis in waterfowl: a new host record. Proc. Am. Assoc. Zoo Vet. 2002: 86-87.

LUTZ A. 1889: Ueber eine Myxosporidium aus der Gallenblase brazilianischer Batrachier (Cystodiscus immersus). Zentralbl. Bakteriol. Parasitol. 5: 84-88.

MCCLELland R.S., MuRPhY M.D., CONE D.K. 1997: Report of spores of Henneguya salminicola (Myxozoa) in human stool specimens: possible source of confusion with human spermatozoa. J. Clin. Microbiol. 35: 2815-2818.

Moncada L.J., LOPEZ M.C., MurCia M.L., Nicholls S., FreCIA L., GuiO O.L., CORREdor A. 2001: Myxobolus sp., another opportunistic parasite in immunosuppressed patients? J. Clin. Microbiol. 39: 1938-1940.

PUCEK Z. 1955: Untersuchungen über die Veränderlichkeit des Schädels im Lebenszyklus von Sorex araneus araneus L. Ann. Univ. M. Curie-Sklodowska, Lublin, Poland, Sect. C, 9: 163-217.

PUCEK Z. 1957: Histomorphologische Untersuchungen über die Winterdepression des Schädels bei Sorex L. und Neomys Kaup. Ann. Univ. M. Curie-Sklodowska, Lublin, Poland, Sect. C, 19: 400-431.

PUCEK Z. 1965: Seasonal and age changes in the weight of internal organs of Sorex araneus L., 1758. Acta Theriol. 10: 369438.

PUCEK Z. 1970: Seasonal and age changes in shrews as an adaptive process. Symp. Zool. Soc. Lond. 26: 189-207. 